\title{
Evaluation of Synergetic Anticancer Activity of Berberine and Curcumin on Different Models of A549, Hep-G2, MCF-7, Jurkat, and K562 Cell Lines
}

\author{
Acharya Balakrishna and M. Hemanth Kumar \\ University of Patanjali, Haridwar, Uttarakhand, India \\ Correspondence should be addressed to Acharya Balakrishna; acharyaji@divyayoga.com
}

Received 5 March 2015; Revised 4 June 2015; Accepted 7 June 2015

Academic Editor: Armelle T. Mbaveng

Copyright (C) 2015 A. Balakrishna and M. H. Kumar. This is an open access article distributed under the Creative Commons Attribution License, which permits unrestricted use, distribution, and reproduction in any medium, provided the original work is properly cited.

\begin{abstract}
Ayurvedic system of medicine is using Berberis aristata and Curcuma longa herbs to treat different diseases including cancer. The study was performed to evaluate the synergetic anticancer activity of Berberine and Curcumin by estimating the inhibition of the cell proliferation by cytotoxicity assay using MTT method on specified human cell lines (A549, Hep-G2, MCF-7, Jurkat, and K562). All the cells were harvested from the culture and seeded in the 96-well assay plates at seeding density of $2.0 \times 10^{4}$ cells/well and were incubated for 24 hours. Test items Berberine with Curcumin (1:1), Curcumin 95\% pure, and Berberine 95\% pure were exposed at the concentrations of 1.25, 0.001 , and $0.5 \mathrm{mg} / \mathrm{mL}$, respectively, and incubated for a period of 48 hours followed by dispensing MTT solution $(5 \mathrm{mg} / \mathrm{mL})$. The cells were incubated at $37 \pm 1^{\circ} \mathrm{C}$ for 4 hours followed by addition of DMSO for dissolving the formazan crystals and absorbance was read at $570 \mathrm{~nm}$. Separate wells were prepared for positive control, controls (only medium with cells), and blank (only medium). The results had proven the synergetic anticancer activity of Berberine with Curcumin inducing cell death greater percentage of $>77 \%$ when compared to pure curcumin with $<54 \%$ and pure Berberine with $<45 \%$ on average on all cell line models.
\end{abstract}

\section{Introduction}

Cancer is the third leading cause of death worldwide, preceded by cardiovascular and infectious diseases. It is a generic term for a group of more than 100 diseases that can affect any part of the body. Chemotherapy is one of the methods of treating cancer. However the chemotherapeutic drugs are highly toxic and have devastating side effects. Various new strategies are being developed to control and treat several human cancers. Over $60 \%$ of anticancer drugs available in the market are of natural origin. Natural products are also the lead molecules for many of the drugs that are in use [1]. Therefore, the phytochemicals present in several herbal products and plants may have the potential to act as preventive or therapeutic agents against various human cancers [2]. Medicinal plants have been in use since time immemorial and their utility has been increasing day by day in the present world. Naturally obtained compounds are considered safer and more easily biodegradable than synthetic compounds and the problem of drug resistance observed in synthetic drugs is also reduced [3]. Plants represent a source of leads for many pharmaceutical compounds and the phytochemical compounds and secondary metabolites present in plants have been used in treating a number of human ailments. Drugs obtained from medicinal plants comprise $25 \%$ of total drugs in developed countries and about $80 \%$ in developing countries [4].

Berberis aristata, commonly known as "Daru haldi," is a spinous herb native to Northern Himalayan region. This plant is widely distributed from Himalayas to Sri Lanka, Bhutan, and hilly areas of Nepal [5]. It contains mainly Berberine a bitter-tasting, yellow, plant alkaloid with a long history of medicinal use in Chinese and Ayurvedic medicine. Berberine, an isoquinoline alkaloid, belongs to the structural class of protoberberines. It is present in the roots, rhizome, and stem bark of a number of important 
medicinal plant species including Hydrastis canadensis (goldenseal), Coptis chinensis (coptis or golden thread), Berberis aquifolium (Oregon grape), and Berberis vulgaris (barberry). Clinical trials have been conducted using Berberine [6]. There is some evidence to support its use in the treatment of trachomas (eye infections), bacterial diarrhea, and leishmaniasis (parasitic disease). Berberine has also shown antimicrobial activity against bacteria, viruses, fungi, protozoans, helminthes (worms), and chlamydia (STD). Future clinical research is warranted in these areas, as well as cancer, cardiovascular disease, skin disorders, and liver disorders [7].

Curcuma longa, a perennial herb and member of the Zingiberaceae (ginger) family, grows to a height of three to five feet and is cultivated extensively in Asia, India, China, and other countries with a tropical climate $[8,9]$. Curcumin, a polyphenol with a diarylheptanoid structure that contains two $\alpha, \beta$-unsaturated ketones, is considered to be the major active constituent of turmeric. The chemical properties and the historical background of Curcumin have been reviewed elsewhere $[10,11]$. This nontoxic natural compound has been reported to possess several biological activities that are therapeutically beneficial to cancer treatment. Turmeric is used extensively in foods for its flavor and color, as well as having a long tradition of use in the Chinese and Ayurvedic systems of medicine, particularly as an anti-inflammatory, and for the treatment of flatulence, jaundice, menstrual difficulties, hematuria, hemorrhage, and colic $[12,13]$. Turmeric can also be applied topically in poultices to relieve pain and inflammation. The active constituents of turmeric are the flavonoid Curcumin. Current research has focused on Curcumin antioxidant, hepatoprotective, anti-inflammatory, anticarcinogenic, and antimicrobial properties, in addition to its use in cardiovascular disease and gastrointestinal disorders $[14,15]$.

Till date researchers had focused on individual phytochemical derivatives to study anticancer activity and by using individual cancer cell lines. For the first time in our study we have studied combination of two different phytochemicals like Berberine from Berberis aristata and Curcumin from Curcuma longa on different types of cancer cell line models like A549 (lung cancer cell line) [3], Hep-G2 (liver cancer cell line), MCF-7 (breast cancer cell line), Jurkat (leukemia cancer cell line), and K562 (kidney cancer cell line) which can bring synergetic activity.

\section{Materials and Methods}

2.1. Preparation of Berberine and Curcumin. The test items Berberine 95\% and Curcumin 95\% were purchased from Patanjali Natural Colorama and stored in ambient conditions for further study.

2.2. Preparation of Stock Solution. Stock concentration of the test items Berberine and Curcumin and their combination in $1: 1$ ratio were prepared by dissolving the test item in $100 \%$ DMSO shown in Table 1 and final stock solution is prepared as shown in Table 2.
TABLE 1: Test system description.

\begin{tabular}{lccc}
\hline S. number & Cell line & Description of cell line & Type of cells \\
\hline 1 & Hep-G2 & Liver cancer cell lines & Adherent cells \\
2 & MCF-7 & Breast cancer cell lines & Adherent cells \\
3 & A549 & Lung cancer cell lines & Adherent cells \\
4 & K562 & Bone cancer cells & Suspension cells \\
5 & Jurkat & Leukemia & Suspension cells \\
\hline
\end{tabular}

2.3. Preparation of Positive Control. $10 \%$ Sodium Lauryl Sulphate (SLS) (w/v) was used as positive control and different concentrations of SLS were used $(10,5,2.5,1.25,0.625$, and 0.312 percent solutions).

2.3.1. Preparation of Negative Control. RPMI medium with $0.5 \%$ DMSO was taken as negative control.

2.4. Description of Cell Lines. All the cell lines described in Table 1 were purchased from National Center for Cell Sciences, Pune, with seeding density of $2.0 \times 10^{4}$ cells/well stored in liquid nitrogen for further testing purpose.

2.5. Preparation of MTT Solution. Stock concentration of $5 \mathrm{mg} / \mathrm{mL}$ MTT was prepared in PBS and sterile filtered with $0.22 \mu$ filter and it was used for the study [3].

2.6. Test System Preparation. Prior to the assay the test system A549, Hep-G2, MCF-7, Jurkat, and K562 cells were propagated at $37 \pm 1^{\circ} \mathrm{C}$ in a gaseous environment of $5 \% \pm 1 \%$ carbon dioxide, in humid environment in tissue culture flasks containing medium, Dulbecco's Modified Eagle Medium (DMEM) (Invitrogen, USA) supplemented with 10\% fetal bovine serum (Invitrogen, USA), and penicillin (100 units) and streptomycin $(100 \mu \mathrm{g})$ antibiotics (Invitrogen, USA) to obtain the subconfluence of cells (70\% to $90 \%$ confluent).

2.6.1. Cell Seeding for Cytotoxicity Assessment. Cell monolayer was rinsed with PBS and aspirated off PBS and cells were trypsinized with $0.25 \%$ Trypsin with $0.2 \mathrm{~g} / \mathrm{L}$ EDTA in tissue culture flask at $37 \pm 1^{\circ} \mathrm{C}$ until the cells detached and floated. DMEM with $10 \%$ FBS was added into the flask to flush out the cells and centrifuged at $900 \mathrm{rpm}$ for 5 minutes. Cells were resuspended in DMEM medium and cell suspension was subjected for the cell count and viability to determine cell number per $\mathrm{mL}$. Cell number was adjusted to $2 \times 10^{5}$ cells $/ \mathrm{mL}$ and $0.1 \mathrm{~mL}$ of the adjusted cells was seeded in each well of 96well cell culture plates. Frequent mixing was done during the seeding, to achieve a uniform cell suspension for plating the cells per well. Plates were designated to indicate its contents and date of experiment. Plates were incubated at $37 \pm 1^{\circ} \mathrm{C}$ for $24 \pm 1 \mathrm{hrs}$ in gaseous environment of $5 \% \pm 1 \%$ carbon dioxide.

After $24 \pm 1$ hrs of incubation the cells were exposed to different concentrations of test items, Table 3, by replacing the spent medium with $100 \mu \mathrm{L}$ of different concentrations of the test items solution and incubated for $48 \pm 1$ hrs at 
TABLE 2: Preparation of initial stock concentration of test items.

\begin{tabular}{|c|c|c|c|c|c|}
\hline S. number & $\begin{array}{l}\text { Test item } \\
\text { name }\end{array}$ & $\begin{array}{l}\text { Initial stock concentration } \\
\text { in } \mathrm{mg} / \mathrm{mL} \text { (highest soluble } \\
\text { conc. in DMSO) }\end{array}$ & $\begin{array}{l}\text { Volume of } \\
\text { DMSO initial } \\
\text { stock in } \mathrm{mL}\end{array}$ & $\begin{array}{l}\text { Volume of DMEM } \\
\text { medium in } \mathrm{mL}\end{array}$ & $\begin{array}{c}\text { Final stock in } \\
\text { DMEM in } \mathrm{mg} / \mathrm{mL} \\
\text { (1st concentration) }\end{array}$ \\
\hline 1 & $\begin{array}{l}\text { Berberine + } \\
\text { Curcumin } \\
\text { (BECU) }\end{array}$ & 250 & 0.025 & 4.975 & 1.25 \\
\hline 2 & $\begin{array}{c}\text { Curcumin } \\
(\mathrm{CU})\end{array}$ & 250 & 0.025 & 4.975 & 1.25 \\
\hline 3 & $\begin{array}{c}\text { Berberine } \\
(\mathrm{BE})\end{array}$ & 100 & 0.025 & 4.975 & 0.5 \\
\hline
\end{tabular}

From the final stock different concentrations of the final working stocks five concentrations were prepared in DMEM medium by 4 -fold and 3-fold serial dilutions as specified in Table 3. Diluted stocks were used for the study.

TABLE 3: Final stock concentrations used in the study.

\begin{tabular}{lcccc}
\hline S. number & $\begin{array}{c}\text { Test item } \\
\text { name }\end{array}$ & $\begin{array}{c}\text { Final stock in } \\
\text { DMEM in } \mathrm{mg} / \mathrm{mL}\end{array}$ & $\begin{array}{c}\text { Final working stock } \\
\text { concentration in RPMI in } \\
\mathrm{mg} / \mathrm{mL}\end{array}$ & $\begin{array}{c}\text { Volume of } \\
\text { DMEM in mL }\end{array}$ \\
\hline 1 & $\begin{array}{c}\text { Berberine }+ \\
\text { Curcumin } \\
\text { (BECU) }\end{array}$ & 1.25 (4-fold) & $0.313,0.078,0.020,0.005,0.001$ & $1.25 \mathrm{~mL}$ \\
\hline 2 & $\begin{array}{c}\text { Curcumin } \\
\text { (CU) }\end{array}$ & 1.25 (4-fold) & $0.313,0.078,0.020,0.005,0.001$ & $1.25 \mathrm{~mL}$ \\
\hline 3 & $\begin{array}{c}\text { (Berberine) } \\
\text { BE }\end{array}$ & 0.5 (3-fold) & $0.16,0.0565,0.019,0.006,0.002$ & $1.67 \mathrm{~mL}$ \\
\hline
\end{tabular}

TABLE 4: Average percent activity of Berberine and Curcumin (1:1).

\begin{tabular}{|c|c|c|c|c|c|}
\hline \multirow{2}{*}{ Concentration in $\mathrm{mg} / \mathrm{mL}$} & \multicolumn{5}{|c|}{ Average percent activity of Berberine and Curcumin $(1: 1)$} \\
\hline & Hep-G2 & A549 & MCF-7 & Jurkat & K562 \\
\hline 1.250 & 99.055 & 99.467 & 90.110 & 112.080 & 167.700 \\
\hline 0.313 & 94.986 & 99.086 & 103.589 & 69.003 & 82.041 \\
\hline 0.078 & 94.110 & 77.913 & 99.021 & 71.054 & 68.217 \\
\hline 0.020 & 18.959 & 16.781 & 21.411 & 21.026 & 51.938 \\
\hline 0.005 & 8.548 & -2.513 & -23.083 & 12.650 & 31.783 \\
\hline 0.001 & 13.260 & 12.947 & -38.948 & 29.573 & 11.370 \\
\hline
\end{tabular}

$37 \pm 1^{\circ} \mathrm{C}$ in gaseous environment of $5 \pm 1 \%$ carbon dioxide. Positive, negative control and blank were dispensed in the designated wells and incubated for $48 \pm 1 \mathrm{hrs}$ at $37 \pm 1^{\circ} \mathrm{C}$ in gaseous environment of $5 \pm 1 \%$ carbon dioxide. At the end of the $48 \pm 1 \mathrm{hrs}$ incubation medium with test item/positive control was removed and cells were incubated for $4 \mathrm{hrs}$ with $20 \mu \mathrm{L}$ of MTT $5 \mathrm{mg} / \mathrm{mL}$ solution. After 4 hours of incubation formazan crystals formed by mitochondrial reduction of MTT were solubilized by adding $150 \mu \mathrm{L}$ of DMSO. Absorbance was read at $570 \mathrm{~nm}$ after $10 \mathrm{~min}$ incubation with vortexing.

2.7. Data Analysis. A decrease in the number of living cells results in a decrease in the metabolic activity in the sample. This decrease directly correlates to the amount of formazan formed as monitored by optical density at $570 \mathrm{~nm}$. Percent viability will be calculated using the following formula [3]:

$$
\begin{aligned}
& \text { \%Viability }=100\left(\frac{\text { O.D Test Item }}{\text { O.D of Control }}\right), \\
& \% \text { Activity }=100-\% \text { Viability. }
\end{aligned}
$$

\section{Results}

Test results and the graphical representation of the study are summarized in Tables 4-7 and represented in Figures 1-8.

3.1. Anticancer Activity on A549 Cells. Pure Berberine and Curcumin were found to have inhibition activity of $64 \%$ 
TABLE 5: Average percent activity of 95\% Curcumin.

\begin{tabular}{|c|c|c|c|c|c|}
\hline \multirow{2}{*}{ Concentration in $\mathrm{mg} / \mathrm{mL}$} & \multicolumn{5}{|c|}{ Average percent activity of $95 \%$ Curcumin } \\
\hline & Hep-G2 & A549 & MCF-7 & Jurkat & K562 \\
\hline 1.250 & 87.281 & 60.572 & 91.339 & 23.566 & 164.271 \\
\hline 0.313 & 73.164 & 67.627 & 51.388 & 77.057 & 88.809 \\
\hline 0.078 & 97.774 & 63.016 & 87.008 & 104.489 & 78.747 \\
\hline 0.020 & 43.297 & 40.120 & 49.814 & 47.257 & 62.320 \\
\hline 0.005 & 6.348 & 1.291 & -22.897 & 33.915 & 81.211 \\
\hline 0.001 & -0.474 & -6.756 & -39.039 & 15.337 & -8.316 \\
\hline
\end{tabular}

TABLE 6: Average percent activity of $95 \%$ Berberine.

\begin{tabular}{|c|c|c|c|c|c|}
\hline \multirow{2}{*}{ Concentration in $\mathrm{mg} / \mathrm{mL}$} & \multicolumn{5}{|c|}{ Average percent activity of $95 \%$ Berberine } \\
\hline & Hep-G2 & A549 & MCF-7 & Jurkat & K562 \\
\hline 0.500 & 85.085 & 64.878 & 87.214 & 85.085 & 23.130 \\
\hline 0.167 & 45.384 & 42.561 & 36.227 & 37.247 & 21.188 \\
\hline 0.056 & 19.290 & 14.390 & 10.655 & -2.023 & 37.236 \\
\hline 0.019 & -1.547 & 32.398 & -17.403 & -3.372 & 37.750 \\
\hline 0.006 & 5.816 & 19.472 & -22.336 & -20.519 & 17.533 \\
\hline 0.002 & 4.136 & 19.797 & -33.741 & -39.348 & 5.768 \\
\hline
\end{tabular}

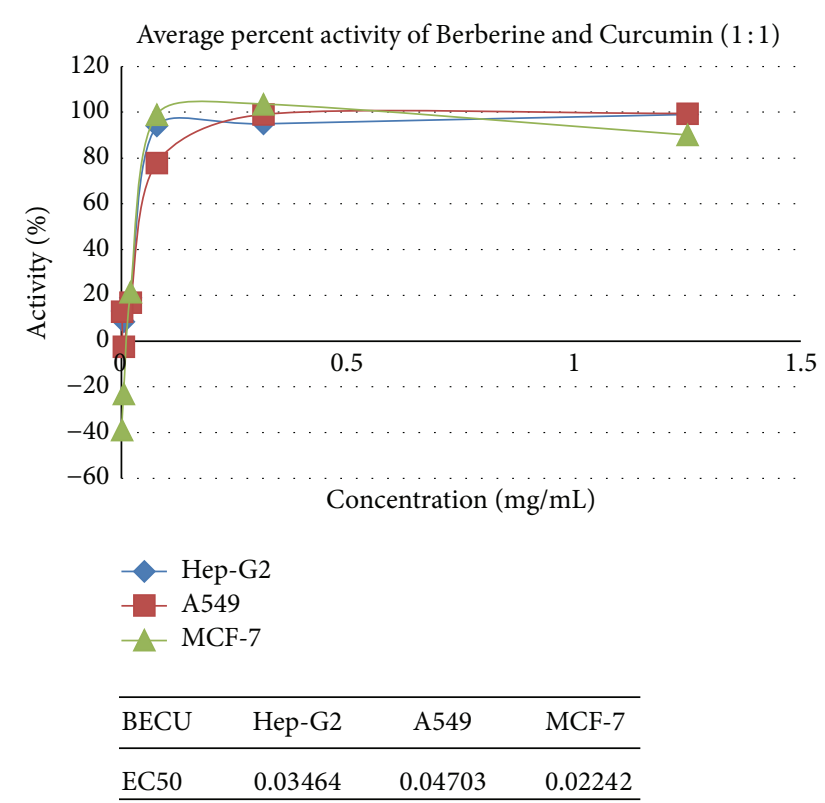

FIGURE 1: Synergetic anticancer activity of Berberine and Curcumin on A549, Hep-G2, and MCF-7.

and $60 \%$, respectively, at a concentration of $0.5 \mathrm{mg} / \mathrm{mL}$ and $1.25 \mathrm{mg} / \mathrm{mL}$ and combination of Berberine and Curcumin in 1:1 ratio was found to bring about $99 \%$ inhibition, respectively, at the concentration of $1.25 \mathrm{mg} / \mathrm{mL}$. Positive control SLS showed the $100 \%$ inhibition activity.

3.2. Anticancer Activity on Hep-G2 Cells. Pure Berberine and Curcumin were found to have inhibitory activity of $85 \%$ and $87 \%$, respectively, at a concentration of $0.5 \mathrm{mg} / \mathrm{mL}$ and $1.25 \mathrm{mg} / \mathrm{mL}$. Combination of Berberine and Curcumin in $1: 1$

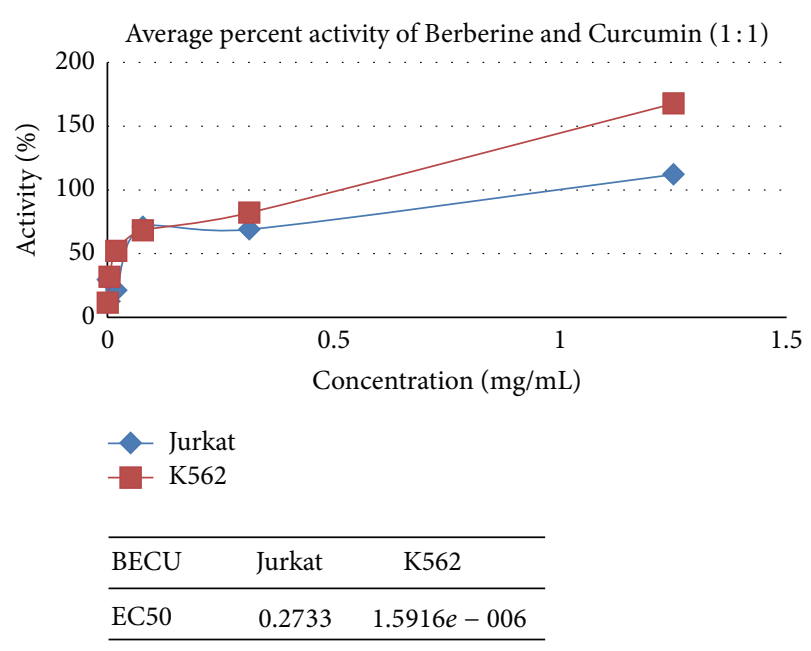

FIGURE 2: Synergetic anticancer activity of Berberine and Curcumin on Jurkat and K562.

ratio was found to bring about $99 \%$ inhibition, respectively, at the concentration of $1.25 \mathrm{mg} / \mathrm{mL}$. Positive control SLS showed the $100 \%$ inhibition activity.

3.3. Anticancer Activity on MCF-7 Cells. Pure Berberine and Curcumin were found to have inhibitory activity of $87 \%$ and $87 \%$, respectively, at a concentration of $0.5 \mathrm{mg} / \mathrm{mL}$ and $1.25 \mathrm{mg} / \mathrm{mL}$. Combination of Berberine and Curcumin in 1:1 ratio was found to bring about $99 \%$ inhibition, respectively, at the concentration of $1.25 \mathrm{mg} / \mathrm{mL}$. Positive control SLS showed the $99 \%$ inhibition activity.

3.4. Anticancer Activity on Jurkat Cells. Pure Berberine and Curcumin were found to have inhibitory activity of $85 \%$ 
TABLE 7: Average percent activity of positive control (SLS).

\begin{tabular}{|c|c|c|c|c|c|}
\hline \multirow{2}{*}{ Concentration in percentage } & \multicolumn{5}{|c|}{ Average percent activity of positive control (SLS) } \\
\hline & Hep-G2 & A549 & MCF-7 & Jurkat & K562 \\
\hline 5.000 & 100.092 & 100.309 & 99.305 & 91.243 & 109.321 \\
\hline 2.500 & 99.610 & 100.247 & 98.861 & 99.553 & 106.180 \\
\hline 1.250 & 99.037 & 101.210 & 98.764 & 106.009 & 116.717 \\
\hline 0.625 & 98.716 & 100.370 & 99.459 & 105.433 & 120.770 \\
\hline 0.313 & 98.097 & 100.111 & 99.768 & 100.000 & 104.762 \\
\hline
\end{tabular}

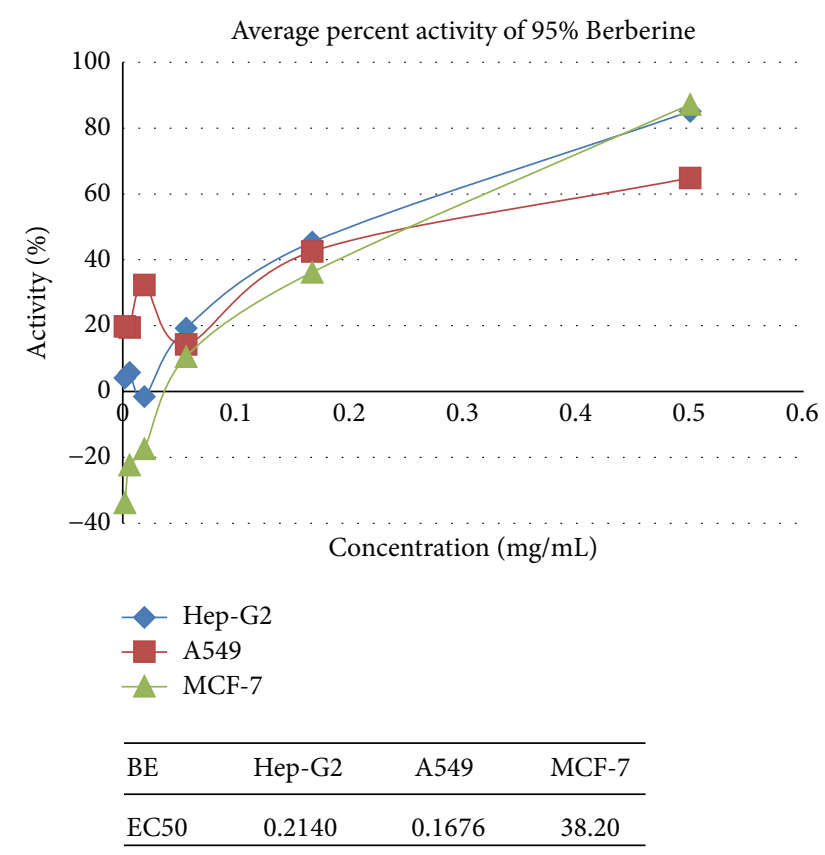

FIGURE 3: Anticancer activity of Berberine on A549, Hep-G2, and MCF-7.

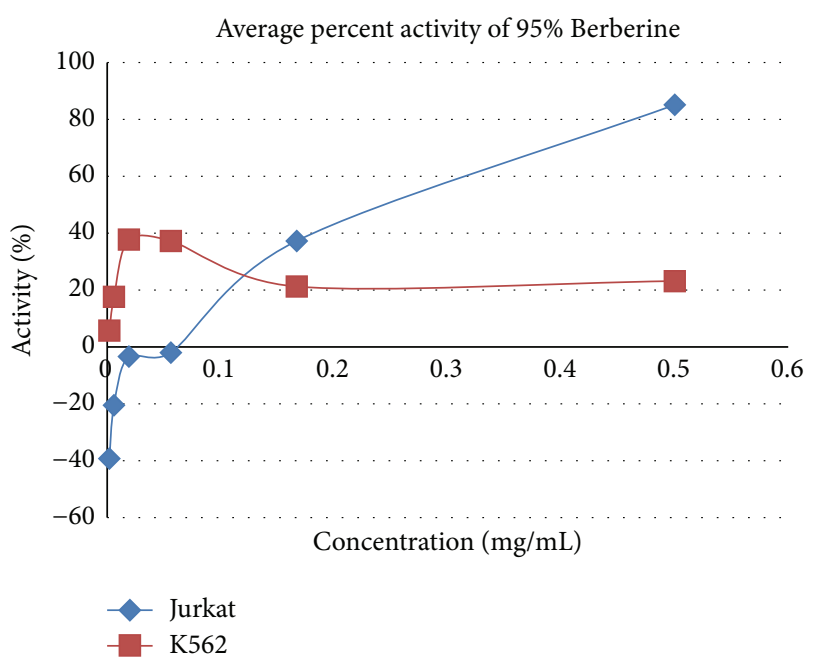

FIGURE 4: Anticancer activity of Berberine on Jurkat and K562.

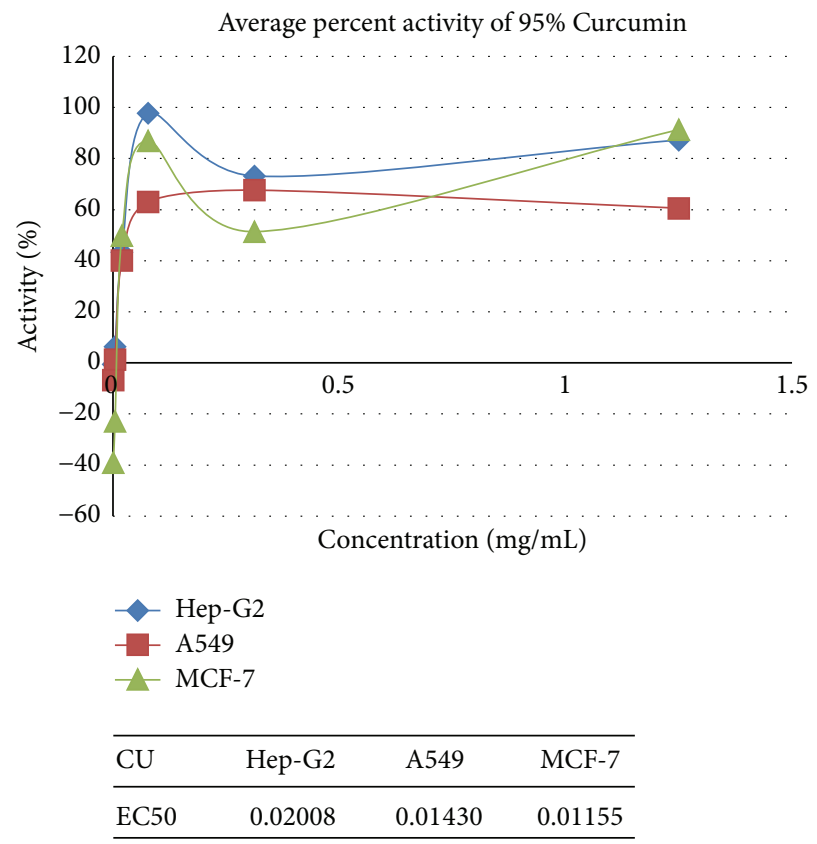

FIgURE 5: Anticancer activity of Curcumin on A549, Hep-G2, and MCF-7.

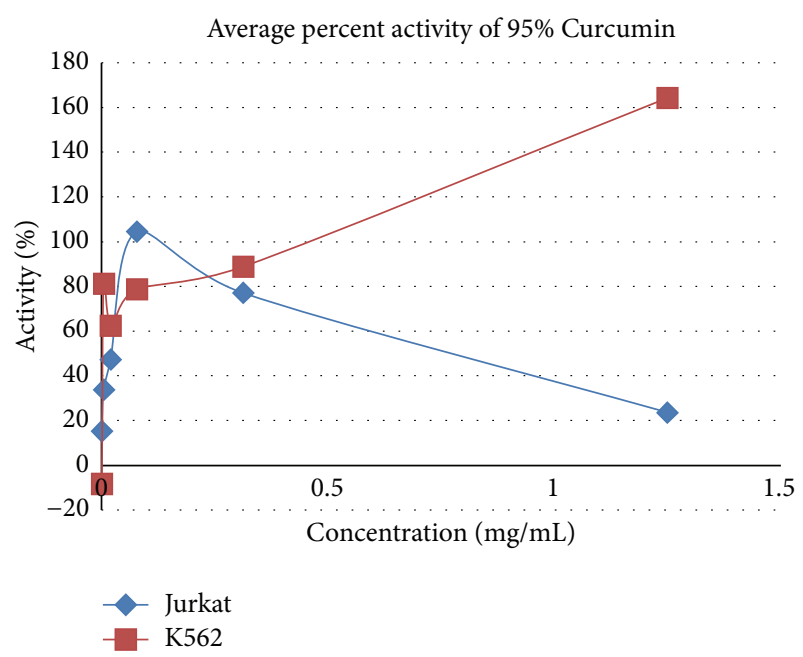

FIGURE 6: Anticancer activity of Curcumin on Jurkat and K562. 


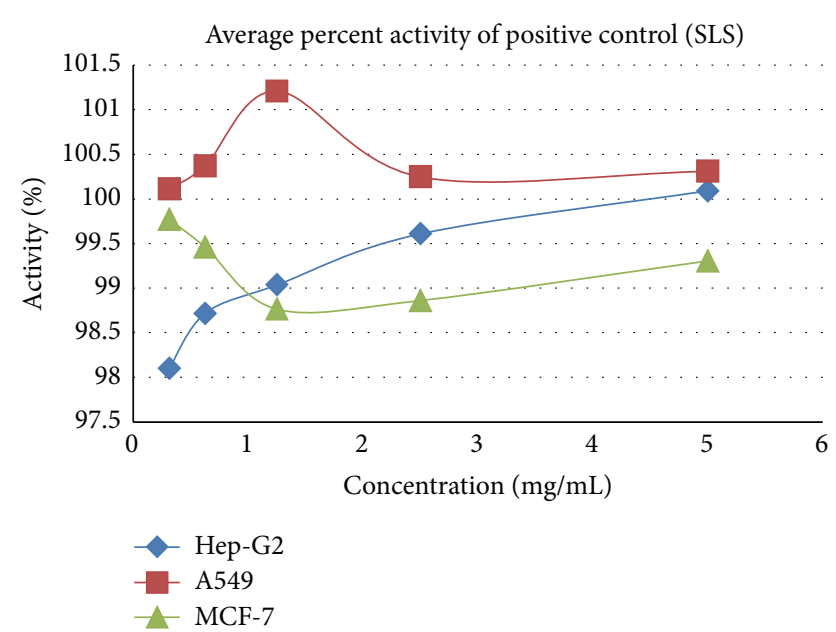

FIGURE 7: Cytotoxicity effect of SLS positive control on A549, HepG2, and MCF-7.

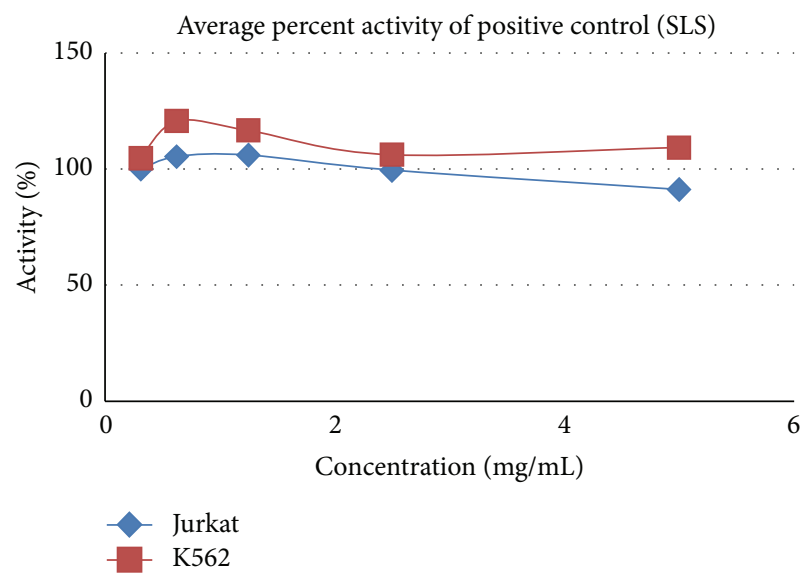

FIGURE 8: Cytotoxicity effect of SLS positive control on Jurkat and K562.

and $23 \%$, respectively, at a concentration of $0.5 \mathrm{mg} / \mathrm{mL}$ and $1.25 \mathrm{mg} / \mathrm{mL}$. Combination of Berberine and Curcumin in $1: 1$ ratio was found to bring about $112 \%$ inhibition, respectively, at the concentration of $1.25 \mathrm{mg} / \mathrm{mL}$. Positive control SLS showed the $100 \%$ inhibition activity.

3.5. Anticancer Activity on K562 Cells. Pure Berberine and Curcumin were found to have inhibitory activity of $23 \%$ and $164 \%$, respectively, at a concentration of $0.5 \mathrm{mg} / \mathrm{mL}$ and $1.25 \mathrm{mg} / \mathrm{mL}$. Combination of Berberine and Curcumin in $1: 1$ ratio was found to bring about $167 \%$ inhibition, respectively, at the concentration of $1.25 \mathrm{mg} / \mathrm{mL}$. Positive control SLS showed the $100 \%$ inhibition activity.

\section{Discussion}

Ayurvedic system of medicine is using Berberis aristata and Curcuma longa herbs to treat different diseases including cancer [5]. The study was performed to evaluate the synergetic anticancer activity of Berberine and Curcumin by estimating the inhibition of the cell proliferation by cytotoxicity assay using MTT method [3] on specified human cell lines (A549, Hep-G2, MCF-7, Jurkat, and K562). All the cells were harvested from the culture and seeded in the 96well assay plates at seeding density of $2.0 \times 10^{4}$ cells/well and were incubated for 24 hours. Test items Berberine with Curcumin (1:1), Curcumin 95\% pure, and Berberine 95\% pure were exposed at the concentrations of $1.25,0.001$, and $0.5 \mathrm{mg} / \mathrm{mL}$, respectively, and incubated for a period of 48 hours followed by dispensing MTT solution $(5 \mathrm{mg} / \mathrm{mL})$. The cells were incubated at $37 \pm 1^{\circ} \mathrm{C}$ for 4 hours followed by addition of DMSO for dissolving the formazan crystals and absorbance was read at $570 \mathrm{~nm}$. Separate wells were prepared for positive control, controls (only medium with cells), and blank (only medium). The exhibited IC-50 values of combination of Berberine and Curcumin were estimated to be $0.034,0.047,0.022,0.2$, and $0.01 \mathrm{mg} / \mathrm{mL}$ in Hep-G2, A549, MCF-7, Jurkat, and K562 cells, respectively. The exhibited IC-50 values of pure Curcumin were estimated to be 0.020 , 0.014, and $0.011 \mathrm{mg} / \mathrm{mL}$ in Hep-G2, A549, and MCF-7 cells, respectively and the IC-50 calculation was not feasible in both the cells Jurkat and K562. The exhibited IC-50 values of pure Berberine were estimated to be 0.20 and $0.1 \mathrm{mg} / \mathrm{mL}$ in HepG2 and A549 but, in MCF-7 IC-50, Jurkat and K562 were unable to be estimated. The in vitro screenings of Berberine and Curcumin combination were found to be having an inhibiting activity against all the three cell lines. Percent inhibition activity at the concentrations $1.25,0.313$, and $0.078 \mathrm{mg} / \mathrm{mL}$ was estimated to be greater than $77 \%$ in A549, Hep-G2, and MCF-7 cells. The in vitro screenings of Berberine and Curcumin combination were found to be having an inhibiting activity against K562 cells. Percent inhibition activity at the concentrations $1.25,0.313$, and $0.078 \mathrm{mg} / \mathrm{mL}$ was estimated to be greater than $68 \%$ in K562 cells. The results had proven the synergetic anticancer activity of Berberine with Curcumin inducing cell death greater percentage of $>77 \%$ when compared to pure Curcumin with $<54 \%$ and pure Berberine with $<45 \%$ on average on all cell line models.

\section{Conclusion}

In conclusion, we confirmed that the combination of Curcumin and Berberine synergistically generates anticancer effects in A549, Hep-G2, MCF-7, Jurkat, and K562 cells in vitro, possibly mediated by inducing apoptosis. With regard to A549, Hep-G2, MCF-7, Jurkat, and K562 Curcurmin and Berberine are of extreme antitumor agents. The combination of Curcumin and Berberine is a novel strategy that has potential in the treatment of cancer patients.

\section{Conflict of Interests}

The authors declare that there is no conflict of interests regarding the publication of this paper. 


\section{References}

[1] G. M. Cragg, D. J. Newman, and K. M. Snader, "Natural products in drug discovery and development," Journal of Natural Products, vol. 60, no. 1, pp. 52-60, 1997.

[2] S. Gupta, D. Zhang, J. Yi, and J. Shao, "Anticancer activities of Oldenlandia diffusa," Journal of Herbal Pharmacotherapy, vol. 4, no. 1, pp. 21-33, 2004.

[3] M. H. Kumar, V. Dhiman, R. Choudhary, and A. Chikara, "Anticancer activity of hydroalcoholic extracts from Paris polyphylla rhizomes against human A549 lung cancer cell lines using MTT assay," International Research Journal of Pharmacy, vol. 5, no. 4, pp. 290-294, 2014.

[4] J. K. Tiwari, R. Ballabha, and P. Tiwari, "Ethnopaediatrics in garhwal himalaya uttarkhand india (psychomedicine and medicine)," New York Science Journal, vol. 3, no. 4, pp. 123-126, 2010.

[5] The Ayurvedic Pharmacopoeia of India, vol. 2, Government of India, Ministry of Health and Family Welfare Department of AYUSH, New Delhi, India, 2007.

[6] M. Imanshahidi and H. Hosseinzadeh, "Pharmacological and therapeutic effects of Berberis vulgaris and its active constituent, berberine," Phytotherapy Research, vol. 22, no. 8, pp. 999-1012, 2008.

[7] K. Inoue, U. Kulsum, S. A. Chowdhury et al., "Tumor-specific cytotoxicity and apoptosis-inducing activity of berberines," Anticancer Research, vol. 25, no. 6, pp. 4053-4059, 2005.

[8] I. N. Dobelis, Ed., Magic and Medicine of Plants, Reader's Digest Association, Pleasantville, NY, USA, 1986.

[9] A. Leung, Encyclopedia of Common Natural Ingredients Used in Food, Drugs, and Cosmetics, vol. 13, John Wiley \& Sons, New York, NY, USA, 1980.

[10] B. B. Aggarwal, A. Kumar, and A. C. Bharti, "Anticancer potential of curcumin: preclinical and clinical studies," Anticancer Research, vol. 23, no. 1, pp. 363-398, 2003.

[11] R. A. Sharma, A. J. Gescher, and W. P. Steward, "Curcumin: the story so far," European Journal of Cancer, vol. 41, no. 13, pp. 19551968, 2005.

[12] B. Wahlstrom and G. Blennow, "A study on the fate of curcumin in the rat," Acta Pharmacologica et Toxicologica, vol. 43, no. 2, pp. 86-92, 1978.

[13] V. Ravindranath and N. Chandrasekhara, "Absorption and tissue distribution of curcumin in rats," Toxicology, vol. 16, no. 3, pp. 259-265, 1980.

[14] S. Toda, T. Miyase, H. Arichi, H. Tanizawa, and Y. Takino, "Natural antioxidants. III. Antioxidative components isolated from rhizome of Curcuma longa L," Chemical and Pharmaceutical Bulletin, vol. 33, no. 4, pp. 1725-1728, 1985.

[15] M. Dikshit, L. Rastogi, R. Shukla, and R. C. Srimal, "Prevention of ischaemia-induced biochemical changes by curcumin and quinidine in the cat heart," Indian Journal of Medical Research, vol. 101, pp. 31-35, 1995. 

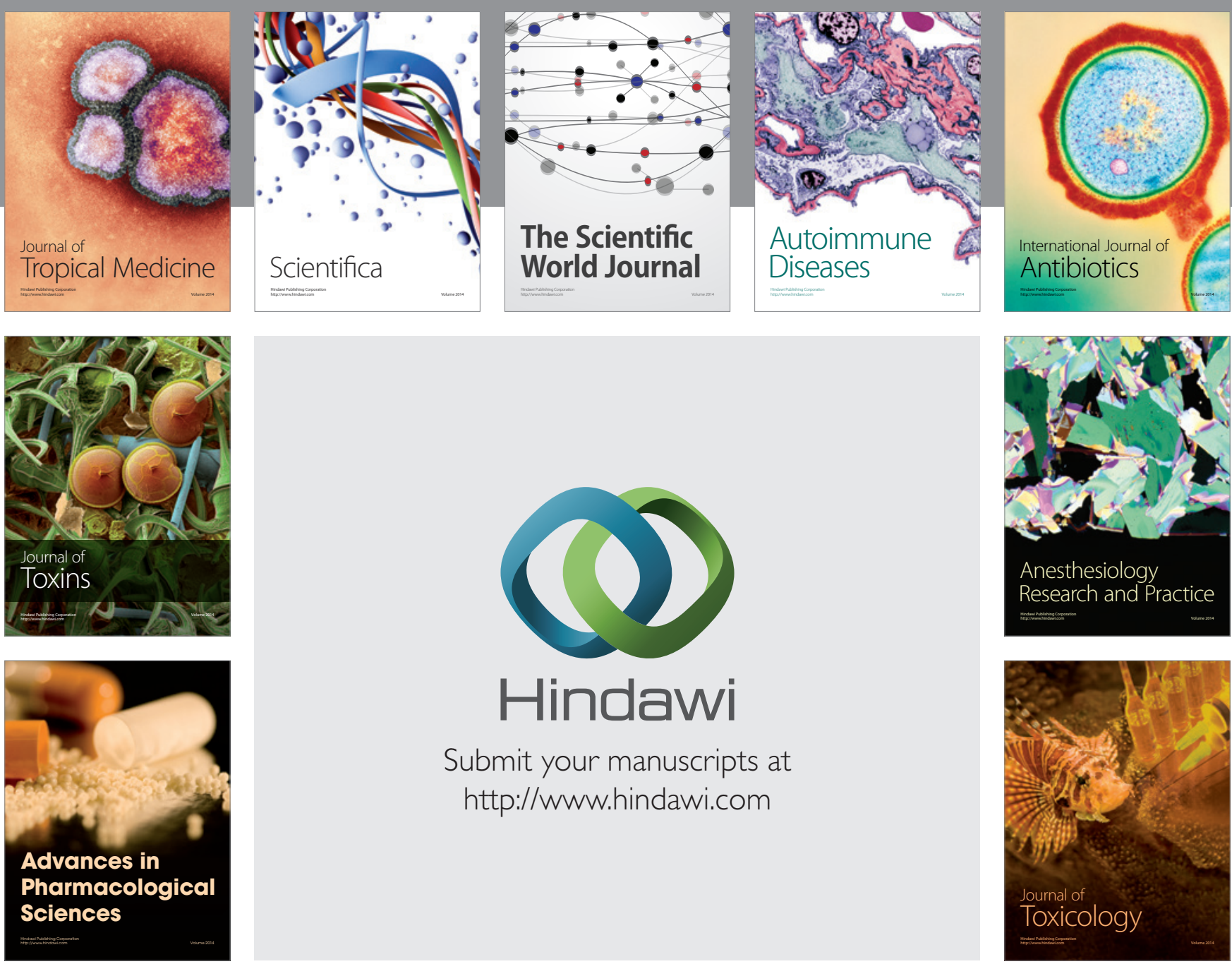

\section{Hindawi}

Submit your manuscripts at

http://www.hindawi.com
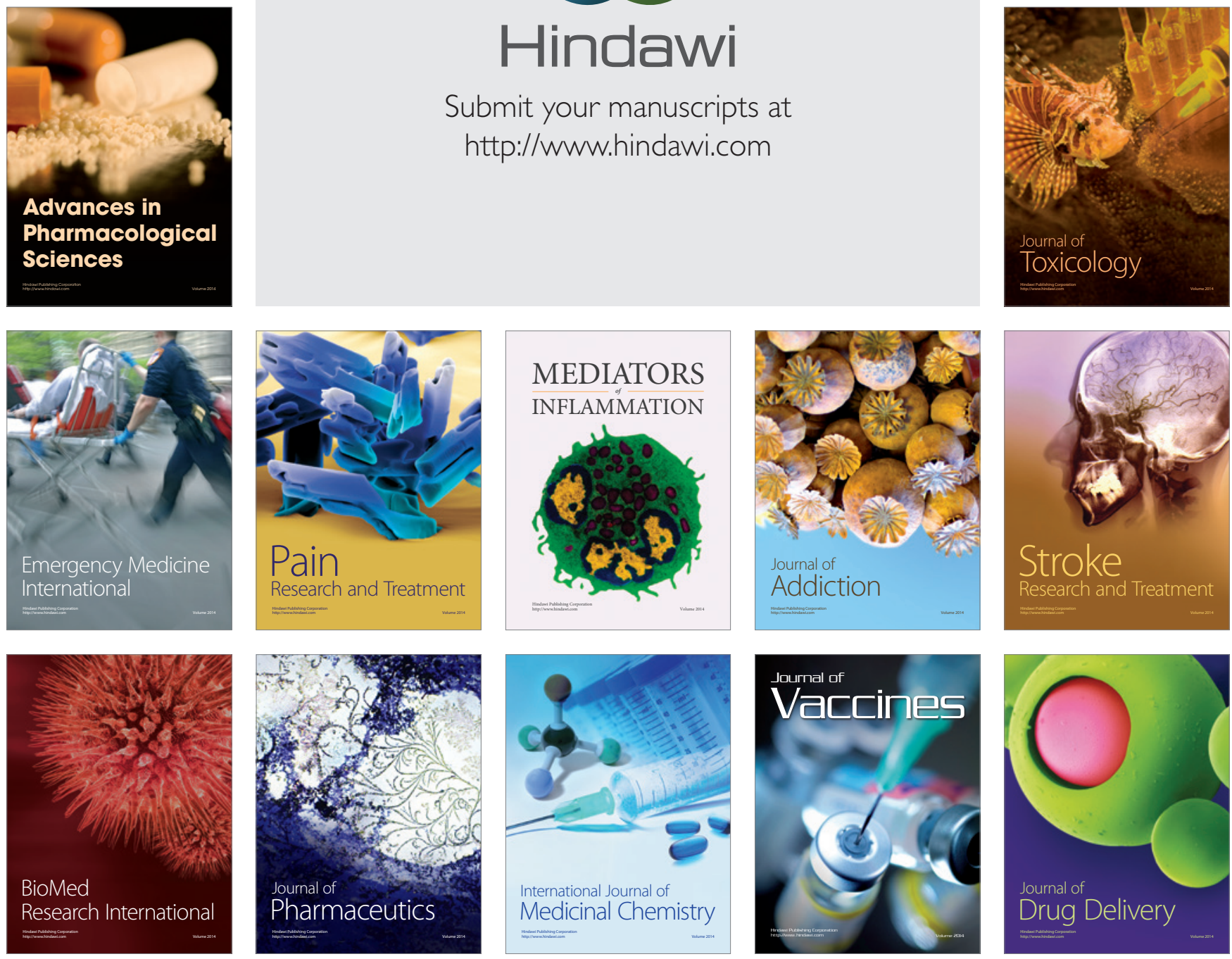